УДК 130.121

https://orcid.org/0000-0002-9577-8282

\title{
МЕТАФОРА СПРИЙНЯТТЯ СВІТУ В КОНТЕКСТІ РОЗДУМІВ ПРО КРИЗУ МЕТАФІЗИЧНОГО ДИСКУРСУ
}

\author{
О.О. Дольська, доктор філософських наук, професор кафедри філософії, \\ Національний технічний університет Харківський політехнічний інститут
}

\begin{abstract}
«Наша душа - це житло. Згадуючи про різні будинки, про
різні "кімнати", ми навчаємося жити всередині самих себе»
\end{abstract}

(Ж. Башляр)

Буттєва структура Світу, тобто реальність, в якій ми існуємо, формується завдяки організачії простору. Сдиним механізмом иьього процесу виступають смисли $i$ значення, якими наповнює людина певні предмети, явища. Так, наприклад, оформлення простору будинку була досить складною прочедурою створення символів, які й визначали саме простір як придатну для житла реальність. Структура світу традиційно реалізується в понятті геометрія Світу. У статті показано, щэо уявлення забраження Світу впливає не тільки на його розуміння $i$ «бачення», але й задає нормативність думки. Метафізичний дискурс залишає нас в Світі-сфері, але сучасна філософія $і$ людина сьогодення облаштовує Світ за допомогою метафори Світ-стільники.

Геометрія Світу представлена метафорою стільників. Таке твердження розглядається в контексті кризи метафізичного дискурсу, матеріал для якої дає постметафізична філософія. На противагу картезіанської парадигми спостерігається звернення філософії до осмислення багаторозмірного топосу людського буття, до його зовнішнім, просторовим формам і проявам. Постметафізичний дискурс свідчить також про зміни в мисленні сучасної людини. Між сприйняттям Світу та думкою, яка оформлюе його, існує зв'язок. Ї̈ можна виразити в наступному: геометрія простору облаштованого Світу є одночасно продуктом $i$ джерелом інтелектуальних зрушень (проблема буття і мислення).

Якщу зміни стосуються світорозуміння, світобудови, то така трансформація образу Світу «тягне» за собою переворот також в світогляді людини і дорівнюється до інтелектуальних револючій. Зміна уявлень про Світ свідчить про зміни характеру мислення людини, а отже перед нами факт онтологічних, вітальних $i$ пізнавальних трансформацій. У сучасній геометрії Світу знаходить свою реалізацію трансверсальний розум, який активізує феномен комунікацій. Отже, просторова метафора Світу, його геометрія і стиль мислення, переплітаючись, впливають один одного.

Актуальність. Буттєва структура Світу, тобто реальність, в якій ми існуємо, формується завдяки організації простору. Сдиним механізмом цього процесу виступають смисли і значення, якими наповнювала людина визначні предмети, явища. Так, наприклад, розбудова простору дому для життя була досить складною процедурою створення символів, які й визначали сам 
простір як реальність, в якій можлива була життєва діяльність людини. Буттєва структура світу традиційно реалізується в понятті геометрія Світу. Наше завдання - показати, що уява про Світ впливає не тільки на його розуміння і «бачення», але й задає нормативність думки. Це питання розглядається в контексті кризи метафізичного дискурсу, що стає свідченням змін у мисленні.

Новизна. Традиційна проблема співвідношення буття та мислення реалізується, перш за все, в образі Світу, для опису якого людина використовує метафору його геометрії. Пропонується використовувати метафору стільників, матеріал для якої дає постметафізична філософія.

\section{Репрезентація світу як життсве-необхідний феномен людства}

Питання про взаємовідносини буття і мислення, яке так бентежило давніх греків і знайшло прояв у філософії Парменіда, зростало саме у межах сферичного, а більш точно - моносферичного мислення. Це дало можливість Сократу і Платону вимагати суворого відношення до висловлювання думок, фіксуючи заданий смисл поняттям (дефініціям), на грунті яких формувалися основні правила-норми організації мислення. Підтвердженням такого доленосного для європейської культури переходу став факт появи правил висловлювання речень-умовиводів: Аристотель сформував положення, структуру та правила формальної логіки. То був час формування першої інтелектуальної революції [1].

Нідерландський мислитель Ф. Анкерсміт на підставі припущень Аристотеля про ідентичність функціонування свідомості i пізнання екстраполюють уявлення Аристотеля про процес пізнання на принципи буття свідомості. Виходить, що свідоме, так само як і чуттєве, здатне приймати форми того, що вони ухвалюють (розуміють). Слідом за Аристотелем Ф. Анкерсміт здійснює свого роду онтологізацію дискурсу, роздум у нього стає об’єктом думки. При цьому об’єкти думки є «об’єктами, які не містять матеріального або, буквально, речі без предмета». Отже, свідомість приймає форму об’єктів навколишнього світу, а форми досвіду і пізнання об'єднують 
світ і людину [2]. Так пише С. Бондаренко, аналізуючи книгу Ф. Анкерсміта «Піднесений історичний досвід». А відомий філолог Ілля Калінін пише про це дуже просто: «Побачивши те, як ми дивимося на світ, ми зможемо побачити сам світ» [3].

3 Нового часу, завдяки науковій раціональності на грунті розвитку природничих наук, монологічний розум все «підводить» до нормативності наукового розуміння як найвищої цінності розуму, що вплинуло на оформлення другої інтелектуальної революції. О. Койре ставить наголос саме на більш глибоких змінах, ніж простий розквіт наукового знання: глибокі духовні або інтелектуальні трансформації формують концептуальний та світоглядний каркас мислення [4]. О. Койре вказує на результат Наукової революції: трансформація світовідчуття і світорозуміння формує особливу ментальність: вона включає базові уявлення про світоустрій, про космічну світобудову. I це не оминуло процес становлення європейської думки. «Головним в «інтелектуальній революції» XVII ст. для О. Койре став космологічний аспект» [5], тобто його буттєва складова.

Отже, між «науковою революцією» і «інтелектуальною революцією» існує складний взаємозв'язок, який виражається в тому, що «наукова революція» $є$ одночасно продуктом і джерелом «інтелектуальної революції». До того ж, революційна боротьба в науці породжує i провокує трансформацію колективних космологічних уявлень, «революцію інтелекту» [6]. Кінець XX ст. і початок XXI дають нам відчуття формування третьої інтелектуальної революції. Які ж підстави вплинули на те, що за масштабами сприйняття світу думки, за допомогою яких описується його геометрія, починають фіксувати нове розуміння Всесвіту та його тлумаченню?

\section{Метафора кулі}

Для людини Всесвіт, як й їі оточення, завжди має визначну структурну характеристику, а топологічний опис реального та реальності завжди вимагає оформлення Світу, де можливі життя, пізнання, присутність, мислення. Філософія свідомості не просто сформувала метафізичний дискурс 
сприйняття Світу, вона оформила Всесвіт в якості імунної системи, яка тягне за собою формування образу Світу, де живе людина і формується мислення не тільки філософського гатунку, але й повсякденного. Дискурс філософії свідомості такі інтенції розцінює як присутність суб'єкта.

П. Слотердайк, розмірковуючи над питанням оформлення Світу за допомогою метафори, звертається до сферичної антропології. Що давала людині метафора Всесвіту як сфери? Сфера, куля, шар задавала нормативність, яка формувалась природним шляхом за рахунок, перш за все, світовідчуття, а вже потім світорозуміння. Буття-в-світі означало буття-всфері. Ментальне світовідчуття геометрії сфери як однозначне підгрунтя почало впливати на усі сфери життєдіяльності: оформлення простору Світу земного та потойбічного, формування нормованої поведінки в домі, на площі та ринку, тобто впливало на соціальні реалії та урбаністичні уподобання, сприяло продукування моралі, ідеології, політичної історії та навіть сновидіння. Отже, «форма кулі як імператив кулі перетворилася в ментальний концепт і надала смертним місце в такому досконалому світі», стверджує німецький філософ [7, с. 30-34].

Інтелект тлумачився також за рахунок сферичної антропології: він зростав і розумівся тільки в контексті ідеї сфери [7, с. 21], що вплинуло на формування мислення. Сфера, шар, куля були наповнені розумом, і це розцінювалося як тіло, основа порядку. У середньовіччі основним розумінням Всесвіту як будови став концепт Ordo (лат. - ряд, порядок), який розцінювався як велика домівка і нагадував сферу, кулю. Екзистенційна аналітика «буття-в» вплинула й на оформлення розуміння розуму і часу. Наприклад, схоласти середньовіччя обгрунтовували розуміння часу саме 3 позиції розуміння геометрії простору, спираючись на синтез раціонального та символічного в уявленнях про просторово-часовий континуум.

Але наприкінці XIX і на початку XX ст. сферична онтологія світу починає свій занепад, а вже з середини XX століття такий стійкий начебто світ почав розхитуватися. Втрата коренів сферичного характеру торкається, а 
потім розхитує вже більш широкий пласт суб'єктивних якостей: він широко захоплює психічну, культурну, соціальну та економічну сфери людини. I, як наслідок, такий врівноважений за рахунок сферичної онтології внутрішній простір людини починає розхитуватися, відчуваючи на собі впливи руйнацій або деструктивних трансформацій. Сфери починають «турбувати» нестабільності, які роблять реальними будь-які ризики, а вітальна сферична геометрія стає нежиттєздатною. Виникло питання про потребу нового розуміння Світу та його топології. На думку П. Слотердайка, сучасний Світ почав унаочнюватися піною [8]. Цю тему німецький філософ описує в своїй тритомній праці «Сфери».

\section{Розбудова Світу-стільників за допомогою метафори складки}

Метафізичний проект загальної моносфери зазнав краху, а мислення сьогодення стало відрізняється від схем моносферного мислення. Добавило інтриги мережево Інтернету: воно трансформувало наш Світ i нашу присутність в ньому, воно постійно змінює фізичну реальність за рахунок не тільки впливу кіберпростору, елементів віртуальності, але й змін в самій людині. Виникає питання: яке воно, мислення, і який розум продукує його? Онтологічна нестабільність світовідчуття i світорозуміння, на думку філософів, свідчить про відхід із метафізичного дискурсу, про розхитування метафізичного стилю мислення. Такі процеси супроводжуються зовсім новим розумінням розуму i особливим характером суб'єктивності, що впливає на його онтологічно-гносеологічне розуміння й має відлуння у новому мисленні.

Сьогодні унаочнюються трансформації у розумінні Всесвіту. Ми пропонуємо його розглядати у вигляді геометрії стільників, метафорою яких є бджолині соти, стільники. Це не безпідставно. Філософія останнім часом рухалась саме до такого розуміння, розгортаючи свої розвідки навколо метафори складки. Ця ідея почала свій відлік 3 початком теми «смерті суб’єкта», завдяки якій пропонували переглянути суб'єктивність, яка була задана моносферним і монологічним розумом. Метафора «смерть суб'єкта» 
як породження постметафізичного дискурсу стала визначати мислення, інтелектуальні зрушення, стала свого роду прапором-символом третьої інтелектуальної революції, яка формується на грунті руйнації метафізичної парадигми. Саме тому Р. Барт описує нову епоху в контексті смерті суб’єкта в невеличкій статті «Смерть автора» (1968), а М. Фуко приходить до такої ж ідеї, але роз’яснює іiі по-іншому в лекції «Що таке автор?» (1969). Певні положення М.Фуко продовжив розвивати Ж. Дельоз, для якого концепт «складка» придбав специфічне значення можливості існування «нової особливої суб’єктивності» і став «зоною суб’єктивації», хоча і не суб’єктивності індивіда в традиційному сенсі цього слова. 3 точки зору Ж. Дельоза, немає суб’єкта, а лише породження суб'єктивності, i для цього є особливі «складчасті зони», а саме - чотири складки суб’єктивації, що мали місце в історії [9].

Метафора смерті суб'єкта розцінюється як опис нового розуміння Світу, де починають привертати увагу не тільки люди як класичні суб'єкти метафізичного дискурсу, але й інші елементи Світу, наприклад, прості речі, що оточують нас. В такому контексті осмислення проблеми «смерті суб'єкта» реалізується завдяки розширенню кола носіїв суб'єктності. I в результаті людина як монопольний суб'єкт класичної філософії зникає.

Свого часу ідею «складки» намагався обгрунтувати М. Мерло-Понті в «Феноменології сприйняття» (1967), цим же поняттям скористався М. Гайдеггер в «Фундаментальних проблемах феноменології» (1982), Ж. Дерріда посилався на метафізичну «складку» в есе про Малларме («Уявний світ Малларме» (1961)). У своєму дослідженні про М. Фуко Ж. Дельоз присвятив цій проблемі цілий розділ під назвою «Складки, або Внутрішня сторона думки (суб'єктивації)» [9]. Ми бачимо, що філософи унаочнюють світ складкою не безпідставно. Треба також звернути увагу на роздуми М. Мерло-Понті про визначення Я як суб’єкта, який викинутий у світ. Останній французький філософ розуміє як прихований горизонт нашого досвіду і як безперервну присутність до будь-якої думки, що її визначає [10]. 
Світ змінюється в залежності від місця присутності в ньому людини. І вже не свідомість вимальовує картину світу, а реальна присутність мого Я задає його бачення. Від місця присутності мого Я як носія не тільки свідомості, а, перш за все, тіла залежить визначення об'єктивності горизонту. Намагання уявити тіло у фізичних вимірах просторовості сприяло формуванню нової метафори світу. Такі вислови М. Мерло-Понті перетинаються із роздумами сучасної дослідниці К. Відаль про світ крізь метафору складки, на які, до речі, посилається й І. Ільїн [11].

На іiі думку, в найзагальнішому вигляді зміст цих міркувань про складку полягає в тому, що матерія сама по собі рухається не по кривій, а по дотичній, утворюючи нескінченно пористу і багату порожнечами текстуру, без будь-якого пробілу, де завжди «каверна всередині каверни, світ, влаштований подібно бджолиному вулику, з неправильними проходами, в яких процес згортання-загортання вже більш не означає просто стисненнярозтиснення, скорочення-розширення, а скоріше деградацію-розвиток». «Складка, - стверджує К. Відаль, - завжди знаходиться «між» двома іншими складками, в тому місці, де дотична зустрічається 3 кривою... вона не співвідноситься ні з якою координатою (тут немає ні верху, ні низу, ні праворуч, ні ліворуч), але завжди «між», завжди «і те, і інше» [12, с. 185]. Дослідниця вважає «складку» символом 80-х років, пояснювальним принципом загальної культурної та політичної дезорганізації світу, де панує «порожнеча, в якій нічого не вирішується, де одні лише ризоми, парадокси, що руйнують здоровий глузд при визначенні чітких меж особистості. Правда нашого становища полягає в тому, що жоден проект не має абсолютного характеру. Існують лише одні фрагменти, хаос, відсутність гармонії, безглуздість, симуляція, тріумф видимостей і легковажності» [12, с. 185]. В складчатих зонах формуються простори сотів, стільників, де присутні різноманітні, але окремі один для одного типи раціональності. 


\section{Трансверсальний розум як підгрунтя комунікації в Світі-просторі}

\section{стільників}

Тему простору з категорією Землі почав розробляти М. Гайдеггер в своїй грунтовній праці «Буття та час», а також в есе про мистецтво «Витоки художнього твору». А от Ф. Гваттарі почав практику деконструкції простору, звернувшись до терміну трансверсальної лінії. Паралельно з'являються концепції інтелектуальних стратегій (Nomadic Thinking, Postmetaphisical Thinking, Complex Thinking, Thinking in Complexity, Global Thinking, Transversal Reason), центральною темою яких стала «тема переходів, перехідних станів між різноманітними типами раціональності, транскультурного, трансдисицплінарного, транспарадигмального мислення» $[13$, c. 93]

Ідеї трансверсальної лінії та трансверсального розуму стали найбільш вдалими для опису простору стільників і комунікації між ними. До математично-геологічного терміну трансверсальний («трансверсальна лінія це діагональний перетин решітки горизонтальних і вертикальних координат, зигзаг, що перериває ланцюг монотонних змін, лінія прогинання горизонтальних порід» [13, с. 94]) вперше звернувся Ж.-П. Сартр, потім Ф. Гваттарі, а в спільних роботах із Ж. Дельозом Ф. Гваттарі став використовувати його як філософське поняття.

Сучасний глобальний Світ формує гетерогенний простір, i він $\epsilon$ простором комунікацій, який спрямований на подолання різного роду кордонів: мовних, політичних, наукових, культурних, релігійних тощо. Так наголошує сучасний фахівець філософії трансверсального розуму - В.Вельш. Онтологічний вимір трансверсальності реалізується як перетин і накладання різних полів суб’єктивності, розмірковує він в книзі «Розум. Сучасна критика розуму і концепт трансверсального розуму» (1995). Розум сам по собі дуже динамічний, а просякнутий культурою, реалізує ії інтенції та здатний долати як власну, так і будь-яку іншу культурну специфіку. Розум завжди детермінований трансцендентністю, а це сприяє активізації зв'язків, 
імплікаціям, глибинним структурам, поперечнім взаємозв'язкам, запозиченням, іграм з аналогіями тощо, які намічають можливі шляхи нового мислення - трансверсального. Отже семантика цього поняття така: трансверсальна лінія - це шлях, дорога «між», вона завжди проходить у просторі «між речами», мета чого - поєднати пункти як відмінності. До речі, інформаційній глобальній мережі потрібен саме такий розум, бо трансверсальний розум «руйнує» як горизонтальні, так i вертикальні структури, породжуючи перехідні об’єкти. Це перетин в онтологічному значенні, який формує різні поля суб’єктивності [14].

В. Вельш розмірковує й над нормативністю: якщо говорити про нормативність або стандарти сучасності, то вони вимагають врахування множинності, яка панує в світі, врівноваженої справедливості по відношенню до різних позицій. Це тягне за собою необхідність їх розуміння, їхньої реконструкції щодо оцінки таких відносин, враховуючи переваги або недоліки, можливі обміни та конфлікти, які стають необхідною складовою отакої нормативності [14].

Для німецького філософа трансверсальність реалізує себе й у сьогоденні простого життя, тому, на його думку, ми потребуємо і все частіше практикуємо цей вид розуму в нашій орієнтації у повсякденні. Тут також ми стикаємося з безліччю варіантів, які походять із різних культур і світоглядів і пропонують безліч розумних пропозицій. Щоб впоратися із цим «плюсом», ми повинні мати можливість слідувати поперек між різними точками зору і перспективами. Ми повинні зробити це, щоб спілкуватися з іншими людьми, а також із самими собою, тому що ми все частіше піддаємося внутрішньому впливу i характеризуємося множинністю. Трансверсальна причина - як справжня здатність до переходу - забезпечує засоби для проходження між цими численними позиціями.

У цих питаннях може бути навіть за доцільне перейти від умов «необхідності» до умов реальної практики. Він вважає, що люди насправді використовують трансверсальний розум в набагато більшому обсязі, ніж 
професійне філософське ставлення у цьому питанні. Люди є експертами 3 трансверсального розуму в більш високому ступені, ніж більшість філософів. Іншими словами: трансверсальне все частіше стає внутрішньою складовою міркувань людей і життєвих планів. «Культурна гібридність» постійно актуалізує свій внесок в трансверсальне. Здається, що трансверсальне все більше характеризує фактичні форми життя багатьох сучасників [15].

В нашому аналізі цікавими $\epsilon$ наступні порівняння. По-перше, співставлення роздумів О. Койре, П. Слотердайка із думками В. Вельша. Вони наголошують на одному й тому самому в формуванні мислення, а саме - на світоглядних переворотах. Наголос ставиться на новому сприйнятті світу і на активізації нових за характером відношень до Світу. Тим самим підкреслюється поява нового характеру мислення, що супроводжується новою поведінкою з боку людини.

По-друге, звернення до роздумів американського філософа К. Шрага, автора книг «Я после постмодернизма» (1999), «Бог как иное, чем существо: к семантике дара» (2002) та «Конвергенция в разнице: философские разговоры через национальные границы» (2004), допоможе усвідомити значення нової геометрії Світу відносно глобальних трансформацій у ментальних характеристиках людини XXI століття. Застосовуючи термін «трансверсальний логос», він робить спробу вийти за рамки постмодерну. А головне - К. Шраг говорить про необхідність вироблення філософського проекту під назвою «порятунок цілісних відмінностей». На його думку, такий порятунок можливий за умов звернення до трансверсального логосу, який і повинен заступити місце універсального. Саме такий логос й має тримати вісь філософії третього тисячоліття [16].

\section{Висновки}

Між образом Світу і думкою, яка оформлює його, існує зв'язок, який декларується в наступному: геометрія простору облаштованого Світу $є$ одночасно продуктом і джерелом інтелектуальних зрушень (проблема буття та мислення). Метафізичний дискурс залишає нас у світі-сфері, але сучасна 
філософія і людина сьогодення облаштовують світ за допомогою метафори

Світ-соти. На противагу картезіанської парадигми спостерігається звернення філософії до осмислення багатопланової топології людського буття, його зовнішнім, просторовим формам і проявам.

Якщо зміни торкаються світорозуміння, світобудови, то така трансформація образу світу «тягне» за собою переворот також у світогляді людини і дорівнюється інтелектуальним революціям. Зміна уявлень про світ свідчить про зміни характеру мислення людини, а отже перед нами - факт онтологічних, вітальних та пізнавальних трансформацій. В сучасній геометрії Світу знаходить свою реалізацію трансверсальний розум, який активізує феномен комунікації. Отже, просторова метафора світу, його геометрія і стиль мислення, переплітаючись, підсилюють один одного.

Список використаних джерел

1. Дольская О.А. Трансформации рациональности в современном образовании / О.А. Дольская // Електрон. pecypc. [Режим доступу] https://core.ac.uk/download/pdf/50574567.pdf

2. Бондаренко С. Франклин Анкерсмит. Возвышенный исторический опыт. Рецензия на книгу / С. Бондаренко // http://urokiistorii.ru/article/2699

3. Калинин И. Приём остранения как опыт возвышенного (от поэтики памяти к поэтике литературы) / И. Калинин // Електрон. pесурс. [Режим доступу] https://elibrary.ru/item.asp?id=15132584

4. Elkana Y. Alexandre Koyré: between the history of ideas and sociology of disembodies knowledge / Y. Elkana // P. Redondi (ed.). Science: The Renaissance of a History. History and Technology. 1987. Vol. 4. P. 115 - 148. // Електрон. pесурс. [Режим доступу] https://www.scribd.com/document/328879949/koyre-pdf

5. Chimisso C. Writing the History of the Mind: philosophy and science in France, 1900 to 1960s. January 2010 / Chimisso C. $/ /$ Електрон. pecypc. [Режим доступу] https://www.researchgate.net/publication/42795371_Writing the History_of the Mind_Philosophy and_Science_i n France 1900 to 1960 s

6. Дольская О. А. От интеллектуальных революций к техникам мышления: на пути к новой парадигме образования / О. Дольская // Science and Education a New Dimension. Humanities and Social Sciences, IV (14), 1.: 89, 2016. - P. 54-59.

7. Слотердайк П. Сферы. Макросферология. - Т.2. Глобусы / П. Слотердайк. - Санкт-Петербург : Наука, 2007.- 1017 c.

8. Слотердайк П. Сферы. Плюральная сферология. - Т.3. Пена / П. Слотердайк. - Санкт-Петербург : Наука, 2007.- 922 с.

9. Делёз Ж. Складка. Лейбниц и барокко (1997) / Ж. Делез // Електрон. ресурс. [Режим доступу] http://yanko.lib.ru/books/philosoph/deleuze=le_pli=leibniz_et_le_baroque=ann.htm

10. Мерло-Понти М. Феноменология восприятия / М. Мерло-Понти // Електрон. ресурс. [Режим доступу] https://vk.com/doc271784829_408075996?hash=9aabf7acb25c2c6fa7\&dl=e338e982c239ea3a43

11. Постмодернизм. Словарь терминов (литературоведение). Составитель: Ильин И. П. 2001. // Електрон. pecypc. [Режим доступу] http://niv.ru/doc/dictionary/postmodernism-literature/index.htm

12. Vidal M. Carmen Africa. The Death of Politics and Sex in the Eighties Show (pp. 171-194) / M. Carmen Africa Vidal // New Literary History. - Vol. 24, - No. 1, Winter, 1993. Culture and Everyday Life // Електрон. pecypc. [Режим доступу] https://www.jstor.org/stable/469277

13. Горбунова Л. Мислення у світі плюральності: проект трансверсального розуму В. Вельша / Л. Горбунова // Філософія освіти. - 2012. - № 1-2. - С. 92-110. // Електрон. ресурс. [Режим доступу] https://cyberleninka.ru/article/v/mislennya-u-sviti-plyuralnosti-proekt-transversalnogo-rozumu-v-velsha

14. Welsch V. Reason: Traditional and Contemporary or Why should we still speak of reason after all? / V. Welsch // Електрон. ресурс. [Режим доступу] 
http://www2.uni-jena.de/welsch/abstracts/W_Welsch_Reason_Traditional_and_Contemporary.html

15. Welsch W. // Електрон. pecypc. [Режим доступу] http://www2.unijena.de/welsch/abstracts/W_Welsch_Subjektsein_Heute.html

16. Schrag Calvin O. and David James Miller. Communication Studies and Philosophy. Convergence Without Coincidence / Calvin Schrag and D/ Miller // The Critical Turn: Rhetoric and Philosophy in Postmodern Discourse. Електрон. pесурс. [Режим доступу] https://books.google.com.ua/books?isbn=080931844X

\section{References}

1. Dolskaya O.A. Transformacy`y` racy`onal'nosty` v sovremennom obrazovany`y` / O.A. Dolskaya // Elektron. resurs. [Rezhy`m dostupu] https://core.ac.uk/download/pdf/50574567.pdf

2. Bondarenko S. Franklyn Ankersmyt. Vozvыshennыj y`story`chesky`j opыt. Recenzy`ya na kny`gu / S. Bondarenko // http://urokiistorii.ru/article/2699

3. Kalynyn Y'. Pry 'ëm ostraneny`ya kak opыt vozvыshennogo (ot poэty 'ky` pamyaty` k poэty 'ke ly`teraturы) / Y'. Kaly`ny`n // Elektron. resurs. [Rezhy`m dostupu] https://elibrary.ru/item.asp?id=15132584

4. Elkana Y. Alexandre Koyré: between the history of ideas and sociology of disembodies knowledge / Y. Elkana // P. Redondi (ed.). Science: The Renaissance of a History. History and Technology. 1987. Vol. 4. P. 115 - 148. // Elektron. resurs. [Rezhy`m dostupu] https://www.scribd.com/document/328879949/koyre-pdf

5. Chimisso C. Writing the History of the Mind: philosophy and science in France, 1900 to 1960s. January 2010 / Chimisso C. // Elektron. resurs. [Rezhy`m dostupu]

https://www.researchgate.net/publication/42795371_Writing_the_History_of_the_Mind_Philosophy_and_Science_i n_France_1900_to_1960s

6. Dolskaya O. A. Ot y’ntellektual 'nux revolyucy'j k texny'kam mushleny'ya: na puty` k novoj parady'gme obrazovany'ya / O. Dol'skaya // Science and Education a New Dimension. Humanities and Social Sciences, IV (14), 1.: 89, 2016. - P. 54-59.

7. $\quad$ Sloterdajk P. Sferы. Makrosferology’ya. - T.2. Globusы / P. Sloterdajk. - Sankt-Peterburg : Nauka, 2007.$1017 \mathrm{~s}$.

8. Sloterdajk P. Sferb. Plyural’naya sferology`ya. - T.3. Pena / P. Sloterdajk. - Sankt-Peterburg : Nauka, 2007.$922 \mathrm{~s}$.

9. Delëz Zh. Skladka. Lejbny`cz y` barokko (1997) / Zh. Delez // Elektron. resurs. [Rezhy`m dostupu] http://yanko.lib.ru/books/philosoph/deleuze=le_pli=leibniz_et_le_baroque=ann.htm

10. Merlo-Ponty M. Fenomenology'ya vospry'yaty'ya / M. Merlo-Ponty'// Elektron. resurs. [Rezhy'm dostupu] https://vk.com/doc271784829_408075996?hash=9aabf7acb25c2c6fa7\&dl=e338e982c239ea3a43

11. Postmodernyzm. Slovar` termy`nov (ly`teraturovedeny`e). Sostavy`tel': Y'l'y`n Y`. P. 2001. // Elektron. resurs. [Rezhy`m dostupu] http://niv.ru/doc/dictionary/postmodernism-literature/index.htm

12. Vidal M. Carmen Africa. The Death of Politics and Sex in the Eighties Show (pp. 171-194) / M. Carmen Africa Vidal // New Literary History. - Vol. 24, - No. 1, Winter, 1993. Culture and Everyday Life // Elektron. resurs. [Rezhy'm dostupu] https://www.jstor.org/stable/469277

13. Gorbunova L. My'slennya u sviti plyural 'nosti: proekt transversal'nogo rozumu V. Welsha / L. Gorbunova // Filosofiya osvity`. - 2012. - \# 1-2. - S. 92-110. // Elektron. resurs. [Rezhy`m dostupu] https://cyberleninka.ru/article/v/mislennya-u-sviti-plyuralnosti-proekt-transversalnogo-rozumu-v-velsha

14. Welsch V. Reason: Traditional and Contemporary or Why should we still speak of reason after all? / V.

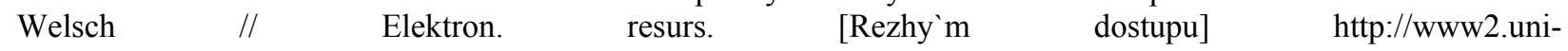
jena.de/welsch/abstracts/W_Welsch_Reason_Traditional_and_Contemporary.html

15. Welsch W. // Elektron. resurs. [Rezhy'm dostupu] http://www2.unijena.de/welsch/abstracts/W_Welsch_Subjektsein_Heute.html

16. Schrag Calvin O. and David James Miller. Communication Studies and Philosophy. Convergence Without Coincidence / Calvin Schrag and D/ Miller // The Critical Turn: Rhetoric and Philosophy in Postmodern Discourse. Elektron. resurs. [Rezhy`m dostupu] https://books.google.com.ua/books?isbn=080931844X

\section{МЕТАФОРА ВОСПРИЯТИЯ МИРА В КОНТЕКСТЕ РАЗМЫШЛЕНИЙ О КРИЗИСЕ МЕТАФИЗИЧЕСКОГО ДИСКУРСА}

Дольская О.А.

Бытийная структура Мира, то есть реальность, в которой мы существуем, формируется благодаря организации пространства. Единственным механизмом этого процесса выступают смыслы и значения, которыми наполняет человек определенные предметы, явления. Так, например, оформление пространства дома была достаточно сложной процедурой создания символов, которые и определяли само пространство как пригодную для жилья реальность. Структура мира традиционно реализуется в понятии 
геометрия Мира. В статье показано, что представление о пространственной характеристике Мира влияет не только на его понимание и «видение», но и задает нормативность мысли. Метафизический дискурс оставляет нас в Мире-сфере, но современная философия и человек настоящего обустраивает Мир с помощью метафоры Мир-соты.

Геометрия Мира представлена метафорой сотов. Такое утверждение рассматривается в контексте кризиса метафизического дискурса, материал для которой дает постметафизическая философия. В противовес картезианской парадигме наблюдается обращение философии к осмыслению многоразмерности топологии человеческого бытия, его внешним, пространственным конфигурациям и проявлениям. Постметафизический дискурс свидетельствует также об изменении в мышлении. Между образом Мира и мыслью, которая оформляет его, существует связь. Ее можно выразить в следующем: геометрия пространства обустроенного Мира является одновременно продуктом и источником интеллектуальных сдвигов (проблема бытия и мышления).

Если изменения касаются миропонимания, мироздания, то такая трансформация образа Мира «тянет» за собой переворот также в мировоззрении человека и приравнивается к интеллектуальным революциям. Изменение представлений о Мире свидетельствует об изменениях характера мышления человека, а следовательно перед нами - факт онтологических, витальных и познавательных трансформаций. В современной геометрии Мира находит свою реализацию трансверсальном разум, который активизирует феномен коммуникаций. Итак, пространственная метафора Мира, его геометрия и стиль мышления, переплетаясь, влияют друг друга.

\section{METAPHOR OF THE PERCEPTION OF THE WORLD IN THE CONTEXT OF REFLECTION ABOUT THE CRISIS OF METAPHYSICAL DISCOURSE}

\section{O. Dolska}

The existential structure of the World, that is, the reality in which we exist, shaped by the organization of space. The only mechanism of this process is the meanings and meanings with which a person fills certain objects, phenomena. For example, the design of the space of the house was quite a complicated procedure for creating symbols, which defined the space itself as a habitable reality. The structure of the world traditionally implemented in the concept of the geometry of the World. The article shows that the idea of the spatial characteristics of the World affects not only its understanding and "vision", but also sets the normativity of thought.

The geometry of the World represented by the metaphor of combs. This statement considered in the context of the crisis of metaphysical discourse, the material for which provided by post-metaphysical philosophy. In contrast to the Cartesian paradigm, there observed an appeal of philosophy to the subject of the philosophy of the body, landscape, to the understanding of the multidimensionality of the spatial configurations and manifestations. Post metaphysical discourse also indicates a change in thinking. There is a connection between the image of the World and the thought that shapes it. It can be expressed in the following: the geometry of the space of the equipped World is both a product and a source of intellectual shifts (the problem of being and thinking). Metaphysical discourse leaves us in the World-sphere, but modern philosophy and the man of the present equip the World with the help of the metaphor of the World-Cell. If the changes relate to the World outlook, the universe, then such a transformation of the image of the World "pulls" behind itself a revolution also in the human worldview and equated with intellectual revolutions. The change in ideas about the World indicates a change in the nature of human thinking, and therefore we faced with the fact of ontological, vital and cognitive transformations. In the modern geometry of the World, the transversal mind finds its realization, which activates the phenomenon of communications. Therefore, the spatial metaphor of the World, its geometry and style of thinking, intertwining, influence each other.

However in the late nineteenth and early twentieth centuries. The spherical ontology of 
the world begins its decline, and since the middle of the twentieth century, such a steady as if the world began to shake. The loss of the roots of a spherical nature touches, and then shakes the wider layer of subjective qualities: it broadly captures the mental, cultural, social and economic spheres of man. In addition, as a result, such a balanced by the spherical ontology of the internal human space begins processes of destruction or destructive transformations. Spheres are beginning to break up the instabilities that make any risks real, and the welcome spherical geometry becomes unviable. The question arose about the need for a new understanding of the world and its topology.

Today we see transformations in the understanding of the universe. We propose to consider it in the form of cell geometry, the metaphor of which are bee cells, cells. It is not unreasonable. Philosophy has recently moved precisely to such an understanding, expanding its intelligence around the metaphor of the fold, the theme of "the death of the subject," and the subjects of subjection. Expanding the reflection around the question of a new metaphor of the world, there is a question about the nature of the mind of this space.

Modern global world creates a heterogeneous space, and it is a space of communication, aimed at overcoming all sorts of borders, language, political, scientific, cultural, religious and so on. To overcome different types of rationality, for communication between them necessary becomes a transversal mind in the new conditions. 